\title{
COVID-19 Cases Admitted to Hospital for Other Reasons
}

\section{Hastaneye Dig̃er Nedenlerle Kabul Edilen COVID-19 Olguları}

Onur ÜNAL ${ }^{1}$ (IID), Gül Ruhsar YILMAZ1 (IDD), Kag̃an ȘEVIK ${ }^{1}$ (IID), Onur KAYA'(IDD), Esra NURLU TEMEL ${ }^{1}$ (IiD), Füsun Zeynep AKÇAM ${ }^{1}$ (IID), Mümtaz Cem ȘiRiN ${ }^{2}$ (İD), Önder ÖZTÜRK ${ }^{3}$ (IID), Münire ÇAKIR ${ }^{3}$ (IDD), Pınar KARABACAK ${ }^{4}(\bar{I} \mathrm{D})$

\footnotetext{
${ }^{1}$ Department of Infectious Diseases and Microbiology, Süleyman Demirel University Faculty of Medicine, Isparta, Turkey

${ }^{2}$ Department of Medical Microbiology, Süleyman Demirel University Faculty of Medicine, Isparta, Turkey

${ }^{3}$ Department of Chest Diseases, Süleyman Demirel University Faculty of Medicine, Isparta, Turkey
}

Cite this article as: Ünal O, Yılmaz GR, Şevik K, Kaya O, Nurlu Temel E, Akçam FZ, et al. COVID-19 cases admitted to hospital for other reasons. FLORA 2021;26(4):594-602.

${ }^{4}$ Department of Anesthesiology and Reanimation, Süleyman Demirel University Faculty of Medicine, Isparta, Turkey

\section{ABSTRACT}

Introduction: As the pandemic continues, SARS-CoV-2 infection has inevitably been detected in patients hospitalized for other reasons. Detection of SARS-CoV-2 infected cases after hospitalization may lead to delay in taking appropriate infection control measures.

Materials and Methods: The present study retrospectively scanned all electronic and hard copy records of the cases presented to the hospital and hospitalized for other reasons and then diagnosed as COVID-19 in Suleyman Demirel University Faculty of Medicine, Research and Training Hospital between 01 April 2020 and 31 December 2020.

Results: Accordingly, 22 cases were decided as community-acquired, 3 cases as probable community-acquired, 5 cases as hospital-acquired, and 4 cases as probable hospital-acquired. The reason for sampling for SARS-CoV-2 was determined as having symptoms compatible with COVID-19 in 23 (67.6\%) of 34 cases, preoperative screening of COVID-19 infection in 9 (26.5\%), and high risky contact in 2 cases (5.9\%). Considering contact histories epidemiologically, it was thought that transmission occurred to 8 healthcare staff from 2 cases, and to other patients or relatives from 8 cases, but sequence analysis could not be performed.

Conclusion: The high number of hospitalized patients diagnosed as COVID-19 creates a significant burden on the healthcare system in terms of infrastructure and management capacity. It is recommended that patients and healthcare professionals be screened widely and thoroughly, especially in conditions where COVID-19 cases are detected in non-COVID-19 units. This kind of screening will allow the potential outbreak to be controlled.

Key Words: COVID-19; Hospitalization; Nosocomial 
ÖZ

\section{Hastaneye Dig̃er Nedenlerle Kabul Edilen COVID-19 Olguları}

\section{Onur ÜNAL', Gül Ruhsar YILMAZ1', Kag̃an ȘEVIK', Onur KAYA', Esra NURLU TEMEL', Füsun Zeynep AKCุAM', Mümtaz Cem ȘiRiN² ${ }^{2}$ Önder ÖZTÜRK ${ }^{3}$, Münire ÇAKIR ${ }^{3}$, Pınar KARABACAK ${ }^{4}$}

\footnotetext{
${ }^{1}$ Süleyman Demirel Üniversitesi Tıp Fakültesi, İnfeksiyon Hastalıkları ve Klinik Mikrobiyoloji Anabilim Dalı, Isparta, Türkiye

2 Süleyman Demirel Üniversitesi Tıp Fakültesi, Tıbbi Mikrobiyoloji Anabilim Dalı, Isparta, Türkiye

${ }^{3}$ Süleyman Demirel Üniversitesi Tıp Fakültesi, Göğüs Hastalıkları Anabilim Dalı, Isparta, Türkiye

${ }^{4}$ Süleyman Demirel Üniversitesi Tıp Fakültesi, Anesteziyoloji ve Reanimasyon Anabilim Dalı, Isparta, Türkiye
}

Giriş: Pandemi ile birlikte hastaneye diğer nedenlerle yatı̧ı yapılan olgularda da SARS-CoV-2 infeksiyonu saptanmaya başlamıştır. SARS-CoV-2 ile infekte olguların hastaneye yatıştan sonra saptanması, gerekli infeksiyon önlemlerinin alınmasında gecikmeye yol açabilmektedir.

Materyal ve Metod: Süleyman Demirel Tıp Fakültesi Araştırma ve Uygulama Hastanesi'ne 01 Nisan 2020 ve 31 Aralık 2020 tarihleri arasında farklı bir nedenle hastaneye başvuran ve hastaneye yatıştan sonra COVID-19 tanısı alan olguların elektronik ve basılı kayıtları retrospektif olarak taranmıştır.

Bulgular: Yirmi iki vaka toplum kaynaklı, üç vaka olası toplum kaynaklı, beş vaka hastane kaynaklı, dört vaka olası hastane kaynaklı olarak tespit edildi. SARS-CoV-2 açısından tetkik istenme nedeni otuz dört olgunun 23'ünde (\%67.6) COVID-19 uyumlu semptom olmaSI, 9'unda (\%27.3) operasyon öncesi COVID-19 infeksiyonu açııından tarama yapılması, iki olguda yüksek riskli temas (\%5.9) olarak tespit edilmiştir. Epidemiyolojik olarak temas öyküleri değerlendirildiğinde iki vakadan sekiz sağlık personeline, sekiz olgudan ise diğer hastalara veya refakatçilere bulaş olduğu düşünülmüş, fakat sekans analizi yapılamamıştır.

Sonuç: Hastanede yatan COVID-19 tanısı konan hasta sayısının yüksek olması, sağlık sistemi üzerinde altyapı ve yönetim kapasitesi açısından önemli bir yük oluşturmaktadır. Özellikle COVID-19 dışı ünitelerde COVID-19 vakalarının tespit edildiği durumlarda hastaların ve sağık çalışanlarının yaygın ve detaylı olarak taranması önerilmektedir. Bu tür bir tarama, potansiyel salgının kontrol altına alınmasına katkı sağlayacaktır.

Anahtar Kelimeler: COVID-19; Hospitalizasyon; Nozokomiyal

\section{INTRODUCTION}

With the pandemic, SARS-CoV-2 infection has started to be detected in patients admitted to hospital for other reasons. Majority of the cases are community-acquired, and the remaining few are hospital-acquired ${ }^{[1]}$. The fear of hospital-acquired COVID-19 causes a decrease in hospital presentations, and the fact that some cases are detected after hospital admission may lead to delays in taking necessary infection control measures. The aim of this study was to determine the ratio of late-diagnosed COVID-19 cases hospitalized for other reasons and nosocomial COVID-19 cases among these patients.

\section{MATERIALS and METHODS}

The present study retrospectively scanned all electronic and hard copy records of the cases presented to the hospital for other reasons and then transferred to the COVID-19 unit in Süleyman Demirel University Faculty of Medicine, Research and Training Hospital between 01 April 2020 and 31 December 2020.

The Ethics Committee of Süleyman Demirel University Hospital approved this study (2//11/2020-349). The study was performed in accordance with the Declaration of Helsinki, and the need for written informed consent was waived due to its retrospective nature.

Demographic data of the patients, the clinic the patients were followed in, the reason of admittance, the reason of performing SARS-CoV-2 PCR test, date of positivity, history of surgical intervention, laboratory and radiological findings compatible with COVID-19, the number of people with whom the patient shared the room before diagnosis, presence of a hospital 
attendant, and whether other patients, attendants and healthcare personnel were infected or not were all recorded on a pre-prepared form.

Grouping of the cases as community-acquired and hospital-acquired was carried out by a research assistant and faculty member of Infectious Diseases and Clinical Microbiology. The classification of the groups was composed by changing the definitions of the European Centre for Disease Prevention and Control (ECDC) $)^{[2]}$. Definitions are as shown below:

\section{Community-Acquired COVID-19}

Cases with close contact with a patient diagnosed with COVID-19 epidemiologically prior to hospital admission, cases with symptoms during admission and/or those receiving COVID-19 diagnosis within 7 days of hospital admission.

\section{Probable Community-Acquired COVID-19}

Cases with symptoms and laboratory findings compatible with COVID-19 during hospital presentation and/or cases receiving COVID-19 diagnosis within 8-14 days after hospital admission, cases not evaluated for COVID-19 before 8 days, and those without any known exposure in hospital.

\section{Hospital-Acquired COVID-19}

This group consists of the cases whose onset of symptoms and first Polymerase Chain Reaction (PCR) positivity occurred 15 days after hospital admission.

\section{Probable Hospital-Acquired COVID-19}

Cases whose onset of symptoms and first PCR positivity occurred between the 3rd and 7th days of hospital admission and who had known contact in hospital on the first day of admission, cases without any known exposure prior to hospital admission or those whose onset of symptoms and first PCR positivity occurred between the $8^{\text {th }}$ and $14^{\text {th }}$ days of admission, and cases with no known exposure during hospitalization or prior to hospital admission.

\section{COVID-19 Diagnosis}

Diagnosis was made by showing SARS-CoV-2 positivity with PCR in nasopharyngeal swab samples.

\section{Statistical Analysis}

Data were recorded on statistical package for the social sciences (SPSS) 15.0, and frequency and percentage calculations were performed. Mean \pm standard deviation was found for numerical variables.

\section{RESULTS}

A total of 18.054 patients were treated as inpatients during this 9-month period. 573 of these patients $(0.03 \%)$ were followed in COVID-19 services with a definitive diagnosis of COVID-19. During the same period of time, a total of 34 patients (5.9\%), 23 males and 11 females, were determined to have COVID-19 after having been admitted to our hospital for reasons other than COVID-19, and they were included into the study. Mean age of the patients was $60.6 \pm$ 17.2 years (min. 32, max. 80), and the departments they were followed in and their reason of admission are given in Table 1 .

Time of detection of the 34 cases, total number of patients admitted to hospital during the same period, and the number of patients followed with a definitive diagnosis of COVID-19 are shown in Figure 1. COVID-19 cases admitted to the hospital for other reasons were mostly diagnosed in November, and there were no cases detected in April, May, and July.

Twenty-two cases were decided as community-acquired, three cases as probable community-acquired, five cases as hospital-acquired, and four cases as probable hospital-acquired. It was identified that 18 patients (52.9\%) stayed in a single room before diagnosis, and the remaining 16 patients $(47.1 \%)$ were followed in rooms where two or more patients were followed. Infection of other patients/patients' attendants was seen in eight cases (Table 2). Third PCR sample was found positive after a symptom was detected in a case hospitalized to undergo coronary bypass and tested negative preoperatively by PCR test twice. It was considered that seven healthcare workers were probably infected by this case. Another patient was hospitalized in the Internal Medicine department to be investigated for anemia etiology, and COVID-19 PCR of this case was detected positive only one day after admission. It 


\begin{tabular}{lc} 
Table 1. Reason of admission and relevant departments of the patients admitted to hospital for other \\
reasons but diagnosed with COVID-19 \\
Departments admitting the patients and reason of admission & $\mathbf{n}(\%)$ \\
\hline Internal Diseases & $10(29.4)$ \\
Orthopedics & $5(14.7)$ \\
Chest Diseases & $3(8.8)$ \\
General Surgery & $3(8.8)$ \\
Obstetrics and Gynecology & $2(5.9)$ \\
Neurology & $2(5.9)$ \\
Neurosurgery & $2(5.9)$ \\
Plastic and Reconstructive Surgery & $2(5.9)$ \\
Cardiovascular Surgery & $2(5.9)$ \\
Cardiology & $1(2.9)$ \\
Urology & $1(2.9)$ \\
Infectious Diseases and Clinical Microbiology & $1(2.9)$ \\
Hospitalization diagnosis & \\
Surgical intervention* & $6(17.6)$ \\
GlS disease** & $5(14.7)$ \\
Infectious pathology*** & $5(14.7)$ \\
Solid organ malignancy & $3(8.8)$ \\
Pulmonary pathology*** & $3(8.8)$ \\
Pregnancy & $2(5.9)$ \\
Palliative care & $2(5.9)$ \\
Acute renal failure & $1(2.9)$ \\
Investigation of anemia etiology & $1(2.9)$ \\
Heart failure & $1(2.9)$ \\
Ischemic cardiac pathology & $1(2.9)$ \\
Hematologic malignancy & $1(2.9)$ \\
Lumbar disc hernia & $1(2.9)$ \\
Cerebral infarct & $1(2.9)$ \\
\hline
\end{tabular}

*Orthopedic surgery (4), Plastic and Reconstructive Surgery (2).

${ }^{* *}$ Gastrointestinal bleeding (2), ulcerative colitis, cholecystitis, liver cirrhosis.

***Urinary tract infection, catheter associated blood-stream infection, neutropenic fever, septic arthritis, ventriculoperitoneal shunt infection.

${ }^{\star * * *}$ Chronical obstructive pulmonary disease attack, pleural effusion (2).

was considered that one healthcare worker was infected by this case.

It was detected that the reasons for running tests against COVID-19 were the presence of symptoms in $23(67.6 \%)$ of the 34 cases. It was established that the present symptoms were associated with an alternative diagnosis in 17 of the remaining 23 patients. It was determined that the symptoms appeared in an appropriate period in terms of hospital-acquired infection in six cases (Table 3).

Infection control measures taken and enforced during the COVID-19 pandemic are shown in chronological order in Table 4. 


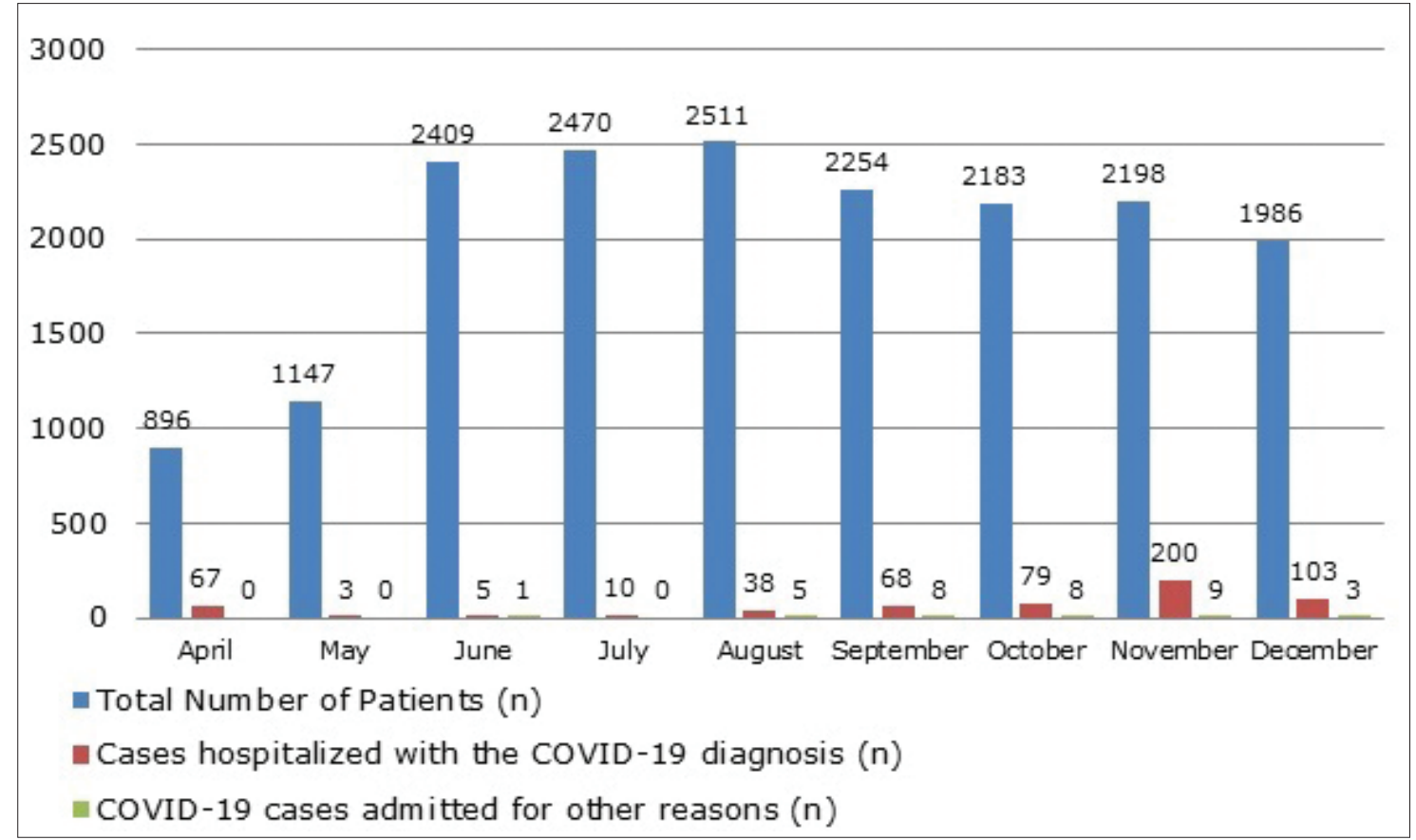

Figure 1. Total number of patients admitted to hospital according to months, the number of patients followed with a definitive diagnosis of COVID-19, and the number of COVID-19 cases admitted to hospital for other reasons.

Table 2. Source of infection of the cases, the rooms they were followed in, status of patients' attendants, infection of other patients or personnel

\begin{tabular}{|c|c|}
\hline & Number of cases $\mathbf{n}(\%)$ \\
\hline \multicolumn{2}{|l|}{ Source of infection } \\
\hline Community-acquired & $22(64.7)$ \\
\hline Possible community-acquired & $3(8.8)$ \\
\hline Hospital-acquired & $5(14.7)$ \\
\hline Possible hospital-acquired & $4(11.8)$ \\
\hline \multicolumn{2}{|c|}{ Number of patients followed in the same room with the case } \\
\hline None & $18(52.9)$ \\
\hline 1 & $8(23.5)$ \\
\hline 2 & $4(11.8)$ \\
\hline 3 & $1(2.9)$ \\
\hline 5 & $3(8.8)$ \\
\hline \multicolumn{2}{|l|}{ Hospital attendants of the cases } \\
\hline Present & $27(79.4)$ \\
\hline None & $7(20.6)$ \\
\hline \multicolumn{2}{|c|}{ Infection of other patients and/or patients' attendants } \\
\hline Yes & $8(23.5)$ \\
\hline No & $26(76.5)$ \\
\hline \multicolumn{2}{|l|}{ Infection of healthcare personnel } \\
\hline Yes & $2(5.9)$ \\
\hline No & $32(94.1)$ \\
\hline
\end{tabular}




\begin{tabular}{|c|c|c|c|c|c|}
\hline $\begin{array}{l}\text { Presence of } \\
\text { symptoms }\end{array}$ & $\begin{array}{l}\text { Community- } \\
\text { acquired }\end{array}$ & $\begin{array}{l}\text { Probable community- } \\
\text { acquired }\end{array}$ & Hospital-acquired & $\begin{array}{c}\text { Probable } \\
\text { hospital-acquired }\end{array}$ & Total \\
\hline Yes & 14 & 3 & 4 & 2 & 23 \\
\hline $\begin{array}{l}\text { No (High risky } \\
\text { contact) }\end{array}$ & 1 & 0 & 0 & 1 & 2 \\
\hline $\begin{array}{l}\text { No (Pre-operative } \\
\text { screening) }\end{array}$ & 7 & 0 & 1 & 1 & 9 \\
\hline Total & 22 & 3 & 5 & 4 & 34 \\
\hline
\end{tabular}

Table 4. Infection control measures taken and enforced during the COVID-19 pandemic

\begin{tabular}{lc} 
Measure & Date \\
\hline Restriction of family visits & 05.02 .2020 \\
Training on PPE use & 05.02 .2020 \\
Triage & 16.03 .2020 \\
Opening COVID-19 polyclinics/emergency room & 16.03 .2020 \\
Cafeteria organization & 17.03 .2020 \\
Instruction of PPE use & 19.03 .2020 \\
Opening definitive and possible COVID-19 services & 19.03 .2020 \\
Cessation of elective surgeries & 19.03 .2020 \\
Implementing ministry algorithm for contact healthcare workers & 26.03 .2020 \\
Turning of ventilation in spaces with no fresh air circulation & 01.04 .2020 \\
N95 use in COVID-19 services and intensive care units & 01.04 .2020 \\
Daily symptom monitoring of the healthcare workers & 01.04 .2020 \\
Daily questioning of inpatients for COVID-19 symptoms & 01.04 .2020 \\
Online continuation of trainings & 06.04 .2020 \\
Opening a COVID-19 intensive care unit & 08.04 .2020 \\
Enforcement of widespread surgical mask use for healthcare personnel & 01.04 .2020 \\
Widespread surgical mask use for patients and their attendants & 15.04 .2020 \\
Preoperative PCR test in predetermined surgeries & 17.04 .2020 \\
Recommendation for the follow-up of patients in single rooms & 14.09 .2020
\end{tabular}

PPE: Personnel protective equipment.

\section{DISCUSSION}

In this period of the pandemic, there have also been asymptomatic cases admitted to hospital for other reasons or symptomatic cases whose symptoms were associated with alternative diagnoses. Non-specific nature of the symptoms and findings, the fact that not detecting SARS$\mathrm{CoV}-2$ in the samples is not sufficient to rule out infection and that lack of adequate evidence about the transmission of the infection by aerosol in the early period of the pandemic, not performing PCR test in all patients admitted to hospital due to limited resources, and various architectural issues were the fundamental reasons of experiencing problems in taking appropriate infection control measures on time. Moreover, long incubation time of COVID-19 and surplus asymptomatic cases or cases with mild symptoms creates the perfect environment in terms of silent infection ${ }^{[3,4]}$.

This study detected 34 cases (5.9\%) that presented to the hospital for reasons other than 
COVID-19 and received COVID-19 diagnosis after hospitalization. In a study by Rhee et al., the rate of patients diagnosed with COVID-19 three days after admission or later has been reported as $1.7 \%^{[1]}$. In our study, the condition of having been detected 3 days after admission or later was not required for cases that presented for reasons other than COVID-19 but diagnosed with COVID-19 upon admission. We are of the opinion that the rate found in this study is therefore higher compared to the study by Rhee et al.

It was determined in 17 of the 34 patients detected in our study that there was one or more than one symptom related to COVID-19, but these symptoms were associated with other diagnoses. Triage was started in our hospital in terms of COVID-19 disease as of March 16, 2020. We believe that alternative diagnoses were also primarily considered in triage due to the fact that these cases were detected after admission to the hospital despite symptoms.

The literature reports different rates in terms of nosocomial COVID-19 infection. It has been reported that at the start of the pandemic and before the identification of infection control measures, 44\% of COVID-19 infections in China would be nosocomial ${ }^{[5]}$. In a series including 42 cases from Hong Kong, it has been reported that there was not any nosocomial case within 6 weeks after virus identification ${ }^{[6]}$. According to a media report from the United Kingdom, 5-7\% of all COVID-19 cases were related to healthcare ${ }^{[7]}$. In a retrospective study conducted in a research and training hospital in London, 15\% of the cases between March 2 and April 12 were reported as definitive or possible nosocomial ${ }^{[8]}$. Since it is difficult to detect the source of infection in cases infected with coronavirus, it is not easy to carry out a nosocomial/community-acquired COVID-19 classification. Different definitions are found in the literature for nosocomial COVID-19 cases. In the classification of nosocomial COVID-19 in the present study, revised definitions of European Center for Disease Control were used ${ }^{[2]}$. Taking the 14-day incubation period reported at the start of the pandemic into account, cases detected 14 days after hospital admission were considered as definitive nosocomial. A total of 5 (1.4\%) nosocomial cases were detected in our study. Four cases were evaluated as possible nosocomial (1.1\%). When possible and definitive nosocomial cases were evaluated together, $2.5 \%$ of the total cases were nosocomial.

High number of COVID-19 inpatients creates an important burden on the healthcare system in terms of infrastructure and management capacity ${ }^{[9,10]}$. The increase in colonization throughout the hospital raises the probability of being infected by SARS-CoV-2 in healthcare workers and patients admitted to the hospital for reasons other than COVID-19[3]. In the institution where the present study was conducted, recommendations related to infection control and isolation given by the Coronavirus Scientific Advisory Board of the Ministry of Health were taken into consideration ${ }^{[11,12]}$. COVID-19 cases were first started to be followed in April 2020. All cases followed in that period were those that came from Hadj and quarantined, and there were no cases that resided in the city. Since the virus had not spread in the community yet, there were no cases detected subsequently in non-COVID-19 services. The number of patients followed for COVID-19 in our hospital in May, June and July was very low, and one patient was admitted to the non-COVID-19 service only in June. Along with the increase in the number of cases as of August, cases admitted to non-COVID services but later detected as COVID-19 were started to be seen again.

Possible and definitive COVID-19 cases in our hospital were followed in different services on two floors in the main building and on two floors in another one. Possible COVID-19 service and definitive COVID-19 service were opened on March $16^{\text {th }}$ and April $1^{\text {st }}$, respectively. Cohorting were made for cases with definitive diagnosis. Possible cases were followed in single rooms until they were diagnosed. As of the start of the pandemic, the Ministry of Health has recommended following patients in non-COVID services in single rooms and questioning the patients daily and during admission in terms of COVID-19[11]. However, due to the number of patients presenting to the hospital and insufficient 
infrastructure of the hospital, two or more patients had to be followed in the same room in some departments. Infection of patients or attendants occurred in eight cases.

In accordance with the recommendations of the Scientific Advisory Board of the Ministry of Health and the instructions of the Provincial Directorate of Health, PCR sample for SARSCoV-2 was taken from symptomatic patients, patients planned to undergo major surgery, and healthcare personnel who had moderate or high risky contact. Universal screening could not be performed in all patients admitted to the hospital. Upon the increase in the number of cases detected in non-COVID-19 services, other departments were informed by the Infection Control Committee in written again to admit patients in single rooms on September 14, 2020. On the same day, a check-list was added on the hospital's information management system in order not to overlook daily questioning of each inpatient in terms of COVID-19. After having started to follow patients diagnosed with COVID-19 in our hospital, patients and their attendants to be admitted to other departments were asked to sign a consent form stating that cases with COVID-19 were followed in the hospital and infection could occur despite all measures taken.

It was considered that seven healthcare workers were infected by a case who tested negative preoperatively for coronavirus on PCR twice but was found positive on the third PCR test performed due to symptom detection following the suspension of isolation measures.

The mentioned case was a warning for all hospital staff in terms of the necessity of continuing daily symptom interrogation and the application of contact and droplet infection control measures, even if the PCR result was negative.

Proper sample taking, sufficient sample, and appropriate follow of procedure are also known as factors affecting PCR result ${ }^{[13]}$.

Another strategy of pandemic control is to follow healthcare personnel daily in terms of COVID-19 symptoms and/or screening by $\mathrm{PCR}^{[3,13,14]}$. In line with the Ministry of Health recommendations, healthcare workers with moderate or high risky contact were isolated for seven days and started duty after seven days by showing PCR negativity if there is no symptom. In the event of detecting a COVID-19 case especially in non-COVID-19 services, it is recommended to perform widespread screening on patients and healthcare personnel ${ }^{[3]}$. This screening will provide the possibility to control a potential epidemic.

Since it is inevitable to encounter asymptomatic patients who are not considered to have COVID-19 infection during the pandemic, single rooms, not allowing visitors and attendants, and proper use of mask along with standard infection control measures will prevent spread of the infection to hospital staff and other patients ${ }^{[15-21]}$. Although a negative result does not show that the individual is not infected, it has been reported that a universal screening in regions with high prevalence might be efficient ${ }^{[22]}$.

\section{ETHICS COMMITTEE APPROVAL}

This study approval was obtained from Süleyman Demirel University Faculty of Medicine Clinical Researches Ethics Committee (Decision No: 349, Date: 02.11.2020).

\section{CONFLICT of INTEREST}

None of the authors had conflict of interest.

\section{AUTHORSHIP CONTRIBUTIONS}

Concept and Design: OU், GRY

Data Collection or Processing: KȘ, ÖÖ, MÇ, PK

Analysis/Interpretation: OK, FZA, MCS

Literature Search: ENT, KȘ

Writing: OU், GRY

Final Approval: OU், GRY

\section{REFERENCES}

1. Rhee $C$, Baker $M$, Vaidya V, Tucker $R$, Resnick $A$, Morris $C A$, et al. Incidence of Nosocomial COVID-19 in Patients Hospitalized at a Large US Academic Medical Center. JAMA Netw Open 2020;3(9):e2020498.

2. European Centre for Disease Prevention and Control. Surveillance Definitions for COVID-19. [Updated 2021. Accessed 2021 February 11]. Available from: https://www.ecdc.europa.eu/en/covid-19/surveillance/surveillance-definitions. 
3. Abbas $M$, Nunes $T R$, Martischang $R$, Zingg $W$, Iten $A$, Pittet $D$, et al. Nosocomial transmission and outbreaks of coronavirus disease 2019: the need to protect both patients and healthcare workers. Antimicrob Resist Infect Control 2021;10(1):7.

4. Arons MM, Hatfield KM, Reddy SC, Kimball A, James A, Jacobs JR, et al. Presymptomatic SARS-CoV-2 infections and transmission in a skilled nursing facility. N Engl J Med 2020;382(22):2081-90.

5. Wang D, Hu B, Hu C, Zhu F, Liu X, Zhang J, et al. Clinical characteristics of 138 hospitalized patients with 2019 novel coronavirus-infected pneumonia in Wuhan, China. JAMA 2020;323(11):1061-9.

6. Cheng VCC, Wong SC, Chen JHK, Yip CCY, Chuang VWM, Tsang OTY, et al. Escalating infection control response to the rapidly evolving epidemiology of the coronavirus disease 2019 (COVID-19) due to SARS-CoV-2 in Hong Kong. Infect Control Hosp Epidemiol 2020;41(5):493-8.

7. The Guardian. Up to $20 \%$ of hospital patients with Covid-19 caught it at hospital. Accessed date: 14.01.2021. Available from: https://www.theguardian.com/world/2020/ may/17/hospital-patients-england-coronavirus-covid-19.

8. Rickman HM, Rampling T, Shaw K, Martinez-Garcia G, Hail $L$, Coen $P$, et al. Nosocomial transmission of COVID-19: a retrospective study of 66 hospital-acquired cases in a London teaching hospital. Clin Infect Dis 2021;72(4):690-3.

9. Griffin KM, Karas MG, Ivascu NS, Lief L. Hospital preparedness for COVID-19: a practical guide from a critical care perspective. Am J Respir Crit Care Med 2020;201(11):133744.

10. Carenzo L, Costantini E, Greco M, Barra FL, Rendiniello $V$, Mainetti $M$, et al. Hospital surge capacity in a tertiary emergency referral centre during the COVID-19 outbreak in Italy. Anaesthesia 2020;75(7):928-34.

11. Republic of Turkey Ministry of Health. Study guide and infection control measures in health institutions. Accessed date: 16.05.2021. Available from: https://covid19.saglik.gov.tr/ TR-66532/saglik-kurumlarinda-calisma-rehberi-ve-enfeksiyon-kontrol-onlemleri.html.

12. Republic of Turkey Ministry of Health. Infection Control and Isolation. Accessed date: 14.06.?? Available from: https:// covid19.saglik.gov.tr/TR-66338/enfeksiyon-kontrolu-ve-izolasyon.html.

13. Infectious Diseases Society of America (IDSA). IDSA Guidelines on the Diagnosis of COVID-19: Moleculer Diagnostic Testing. Accessed date: 15.01.2021. Available from: https://www.idsociety.org/practice-guideline/covid-19-guideline-diagnostics/.
14. Mostafa A, Kandil S, El-Sayed MH, Girgis S, Hafez H, Yosef $M$, et al. Universal COVID-19 screening of 4040 health care workers in a resource-limited setting: an Egyptian pilot model in a university with 12 public hospitals and medical centers. Int J Epidemiol 2020;50(1):50-61.

15. Wong SC, Kwong RT, Wu TC, Chan JWM, Chu MY, Lee SY, et al. Risk of nosocomial transmission of coronavirus disease 2019: an experience in a general ward setting in Hong Kong. J Hosp Infect 2020;105(2):119-27.

16. McMichael TM, Currie DW, Clark S, Pogosjans S, Kay M, Schwartz NG, et al. Epidemiology of Covid-19 in a longterm care facility in King County, Washington. N Engl J Med 2020;382(21):2005-11.

17. Kimball A, Hatfield KM, Arons M, James A, Taylor J, Spicer $K$, et al. Asymptomatic and presymptomatic SARS-CoV-2 infections in residents of a long-term care skilled nursing facility—King County, Washington, March 2020. MMWR Morb Mortal Wkly Rep 2020;69(13):377-81.

18. Patel MC, Chaisson LH, Borgetti S, Burdsall D, Chugh RK, Hoff CR, et al. Asymptomatic SARS-CoV-2 infection and COVID-19 mortality during an outbreak investigation in a skilled nursing facility. Clin Infect Dis 2020;71(11):2920-26.

19. Roxby AC, Greninger AL, Hatfield KM, Lynch JB, Dellit TH, James $A$, et al. Outbreak investigation of COVID-19 among residents and staff of an independent and assisted living community for older adults in Seattle, Washington. JAMA Intern Med 2020;180(8):1101-5.

20. Luong-Nguyen $M$, Hermand $H$, Abdalla S, Cabrit N, Hobeika $C$, Brouquet $A$, et al. Nosocomial infection with SARSCov-2 within Departments of Digestive Surgery. I Visc Surg 2020;157(3s1):13-8.

21. Schneider KN, Correa-Martinez CL, Gosheger G, Rickert C, Schorn D, Mellmann A, et al. Assessing the spreading potential of an undetected case of COVID-19 in orthopaedic surgery. Arch Orthop Trauma Surg 2021;141(7)1-7.

22. Sutton $D$, Fuchs $K, D^{\prime} A$ lton $M$, Goffman $D$. Universal Screening for SARS-CoV-2 in women admitted for delivery. N Engl I Med 2020;382(22):2163-4.

\section{Address for Correspondence/Yazıșma Adresi}

\section{Dr. Onur ÜNAL}

Süleyman Demirel Üniversitesi Tip Fakültesi,

İnfeksiyon Hastalıkları ve

Klinik Mikrobiyoloji Anabilim Dalı

Isparta-Türkiye

E-posta: onurunal_84@hotmail.com 